\title{
THE ROLE OF NON-GOVERNMENTAL ORGANISATIONS - ASSOCIATIONS OF WASTE MANAGEMENT SPECIALISTS AND PRACTITIONERS IN IMPLEMENTATION OF AGENDA 21 IN LATVIA
}

\author{
V. Cudeckis \\ Association of Latvia Waste Management Enterprises \\ $R$. Bendere \\ Waste Management Association of Latvia \\ Latvia
}

According to the main principles of Agenda 21 the environmentally sound management of wastes is among the environmental issues of major concern in maintaining the quality of the Earth's environment and especially achieving environmentally sound and sustainable development in all countries. These principles are adopted in Latvia, too. The safe management of different types of waste is considered to be as an important environmental issue in Latvia only since the 90 's, as after the regaining of independence of the state, Latvia had the opportunity to start with the actual solutions of the main environmental problems. Now it is the Ministry of Environmental Protection and Regional Development (MEPRD), which deals with issues concerning environmental protection and nature conservation in Latvia by integrating them into regional development and construction sectors, as well as by planning balanced and sustainable development of territories and efficient use of natural resources. Today we can state, that the more successes are achieved in the elaboration of politics, legislation and strategy of waste management, and the next step must be the implementation of above mentioned.

Besides the official governmental institutions, the active part in the realizing of the national strategy for waste management is taken by the public organizations such as associations of the waste specialists and practitioners dealing in their every day practice with these questions. The first non-governmental organization of waste management - the Waste Management Association of Latvia (LASA - Latvijas Atkritumu Saimniecibas Asociacija) was established in 1994, it has started with the education of the waste management specialists and elaboration of the practical waste management projects. To rise the education level as for companies which are the implementators of the waste management strategy, as for the organizers of it - municipal 


\section{ECOLOGICAL TECHNOLOGY AND MANAGEMENT \\ KALMAR, SWEDEN, September 22-24, 1999}

authorities, it is one of the basic task. Therefore the Waste Management Association of Latvia is taking the active part in the organization of seminar cycles in waste management for the municipalities as well in the establishment of the education system for waste specialists. The education programs are based on the practical and theoretical knowledge. The participants must past the examinations and prepare some project works before the graduation of the courses. The participants receive the certificates after the successful graduation of courses.

Good support in the realization of the idea of environmental education of our society is the creation of the environmental information centers. Now they are established or will be established in the nearest future in Riga, Jurmala Madona and other parts of Latvia. These centers will help in the realizing the main ideas of Agenda 21 in every day practice. One of the problem discussed in such centers is the waste management system in Latvia. The Waste Management Association of Latvia is taking the active part in the organization and offering the specialist advises, the preparation of different reports, the participation in the seminars and other events. Due to this the municipalities too, which participate in the LASA every day work are forwarding the creation of the new modern system of waste management. Now the LASA together with the Agriculture University department of Environmental Engineering, Jelgava city and Jelgava district municipalities are organizing the exhibition and two days seminar programme in Jelgava. The Association hopes that its efforts will help in the establishment of new contacts and better information flow in the society.

Throughout its existence the different projects concerning the waste field are created for Talsi, Bauska, Jelgava and other cities and districts. A lot of activities were performed within the elaboration of Latvian waste law system.

From the April, 1996 the new public association of waste management practitioners started to work. Association of Latvian Waste Management Enterprises (LASUA - Latvijas Atkritumu saimniecibas uznemeju asociacija) is the employers' union of waste management branch. LASUA represents and defends the economic, social and the professional interests of members of its own by furthering the integrated development of waste management enterprises. In the Association are 35 communal enterprises from 32 towns and districts of Latvia represented in the Association. Fifteen of them are private companies, but other ones - municipal companies. Our communal enterprises are dealing with the maintaining sanitary order in populated areas, including different waste collection, sorting, transporting, deposition and other communal services.

LASUA has four working groups:

1) for work with the ministry, legislation, municipalities, regulations;

2) technical commission;

3) economic commission;

4) for work with other organizations, press, society education, increasing the number of members of our association.

The Functions of our association in the waste management branch are the following:

- Representing the interests of employers' of branch in relations with the State institutions, local municipalities, other international organizations and institutions of branch and employers'.

- Informing its members concerning the legislation, regulations and actualities. 


\section{ECOLOGICAL TECHNOLOGY AND MANAGEMENT \\ KALMAR, SWEDEN, September 22-24, 1999}

- Elaboration and moving the proposals to the competent institutions of legislation for solution the branch problems.

- The Association is offering the consultative assistance and solution of problems connected questions, related with the labor relations, technologies, equipment e.t.c.

- The Association is organizing the training courses, cooperation, exchange of experience on interesting topics for its members.

- The Association is working on the creation and development of waste management system in Latvia, and on the introduction of the best available technology and techniques, creation the preconditions for a successful work.

The main task of this association is to promote the adoption of acceptable systems of solid waste management and of public cleansing, through technological development and improvement of practices, for the protection of the environment and conservation of materials and energy resources. Accordingly to their daily practice, companies are involved in the development of the waste management - it concerns the implementation of the different municipal solid waste collection systems, waste disposal methods such as composting, maintenance of landfills and others.

As an example of the cooperation between the LASUA and municipalities is the creation of the project of Environmental Center in the capital of Latvia. In August, 1998 the project "Riga City Environmental Center "Agenda 21"" was started together with Riga twin city's Norrkopping (Sweden) municipality. The company "Hoetika-ATU" specialists took part in this project as members of the Association.

The fundamental goal of the project is to promote the long term sustainable development at the local level. There are three objectives in order to accomplish this goal:

1. To develop Riga City Environmental Strategy;

2. To create Riga City Environmental Center "Agenda 21", based on Environmental Strategy Document;

3. To create linkages between Riga and Norrkopping and to disseminate the positive experience of the project in Latvia and the Baltic Sea region.

Riga City Environmental Center will be a municipality center for the storing of knowledge and information, for building networks, initiating activities and campaigns, for educational efforts, information at schools and for activities focused on environmental issues.

Special interest in this project is connected with experience which all parts will obtain in network building process, especially between private business structures and municipality structures.

Establishment of such information center, available for everybody, is an urgent need for Riga city where approximately one third of all Latvia's people is living. The purpose is to involve all interest groups into all kinds of environmental activities. The public participation in the waste management field is particularly necessary for sustainable development in Latvia. The LASUA has good opportunity to underline its problems in waste collection system and hand them for solving into the Riga City Environmental Strategy. One of the unsolved questions is the bulk waste collection system in Riga city. The Association would help to organize some bulk waste collection stations in the city. These stations could combine different kinds of waste collection and sorting as well. 


\section{ECOLOGICAL TECHNOLOGY AND MANAGEMENT \\ KALMAR, SWEDEN, September 22-24, 1999}

The LASUA is a member of Latvian Employers' Confederation. It is working in cooperation with Latvian Waste Management Association (LASA), Latvian Packaging Association and other related organizations, and it is planning to become a national member in ISWA.

LASUA and LASA had elaborated proposals for National Municipal Solid Waste Management Strategy, law On Solid Waste and directives concerning the creation and work of new landfills. Both public associations are organizing education, co-operation and exchange of experience in different levels. The associations participate in different projects, such as investment programme 500-, which is under implementation today.

National Municipal Solid Waste Management Strategy considers the solid waste management to be the integrated system which must be realized in practice, introducing a new waste management system, including recycling, improved collection system and using alternative disposal options. The results of the implementation of the strategy depend not only on appropriate tactics of officials, but in great level it will be determined by the practical its realization and the knowledge of the waste management of the companies. Therefore the meaning of public nongovernmental waste management associations is growing day by day. 